\title{
Genotype of human papilloma virus in invasive cervical carcinoma at Dr. Soetomo Hospital Surabaya
}

\author{
Markus Kore', Gondo Mastutik ${ }^{2}$, Sjahjenny Mustokoweni ${ }^{3}$ \\ 'Basic Medical Science Master Program, majoring in Pathobiology, 2,Department of Anatomic Pathology, \\ Faculty of Medicine, Universitas Airlangga, Surabaya
}

\begin{abstract}
ABSTRAK
Tujuan: Mengetahui varian genotipe HPV dan genotipe HPV yang paling sering ditemukan pada ICC di RSUD. Dr. Soetomo Surabaya.

Bahan dan Metode: Rancangan penelitian eksploratif menggunakan pendekatan cross sectional. Sampel berupa 30 blok parafin (formalin fix parrafin embeded=FFPE) yang diperoleh dari penderita squamous cell carcinoma (SCC), adenocarcinoma (AD) dan adenosquamous carcinoma (AS) serviks di RSUD Dr. Soetomo Surabaya periode Januari-Desember 2013. Sampel digunakan untuk ekstraksi DNA yang dilanjutkan PCR dan genotiping HPV.

Hasil: Hasil genotiping menunjukkan 10 positif dari SCC, 6 positif dan 4 negatif dari AD, dan 9 positif dan 1 negatif dari AS. Infeksi HPV pada SCC yaitu infeksi tunggal oleh HPV16, 18, 45, 56 dan infeksi multiple oleh HPV16+45, pada AD yaitu infeksi tunggal oleh HPV16, 18 dan infeksi multiple oleh HPVhr+hr $68 \mathrm{~b}+72$ dan HPVlr $+\mathrm{hr} 6+18+45$, dan pada AS yaitu infeksi tunggal oleh HPVhr 16, 18, 45 dan infeksi multiple oleh HPV lr+hr 6+59.

Simpulan: Infeksi HPV pada ICC adalah infeksi tunggal oleh HPV16, 18, 45, 56 dan infeksi multiple oleh HPV16+45, 68b+72, $6+18+45,6+59$. Genotipe HPV18 memiliki prevalensi paling tinggi pada penderita ICC di RSUD Dr Soetomo Surabaya, diikuti HPV16, 6, 45, 56, 59. (MOG 2017;25:33-40)
\end{abstract}

Kata kunci: Invasive cervical carcinoma, HPV 18, infeksi tunggal, infeksi multipel HPV

\begin{abstract}
Objectives: To identify the variants of genotype HPV that most often found in ICC at Dr Soetomo Hospital Surabaya.

Materials and Methods: This was an explorative study with cross sectional approach. Specimens used were 30 formalin fix parrafin embedded from squamous cell carcinoma (SCC), adenocarcinoma (AD) dan adenosquamous carcinoma (AS) cervival cancer parients at Dr Soetomo Hospital Surabaya around Januari-Desember 2013, then used for DNA virus extraction and continued for PCR and HPV genotyping.

Result : The result of HPV genotyping showed 10 positives from SCC, 6 positives and 4 negatives from AD, and 9 positives and 1 negative from AS. HPV infections in SCC were single infection by HPV $16,18,45,56$, and multiple infection by HPV $16+45$, in AD were single infection by HPV 16,18, anad multiple infection by HPVhr+hr $68 b+72$ and HPVlr+hr $6+18+45$, and in AS were single infection by HPVhr 16, 18, 45 and mutiple infection by HPV $1 \mathrm{r}+\mathrm{hr} 6+59$.

Conclusion : Infections HPV in ICC were single infection by HPV16, 18, 45, 56 and mutiple infection by HPV16+45, 68b+72, $6+18+45,6+59$. HPV 18 has highest prevalence in ICC patient from Dr Soetomo Hospital, followed by HPV16, 6, 45, 56, 59. (MOG 2017;25:33-40)
\end{abstract}

Key words: Invasive cervical carcinoma, HPV 18, Single infection HPV, multiple infection HPV

Correspondence: Gondo Mastutik, Departemen Patologi Anatomi, Fakultas Kedokteran, Universitas Airlangga, J1. Prof. Dr. Moestopo 47, Surabaya 60131, Telp 62-31-5020251 psw 182, Fax 62-31- 5026333, E-mail: gondomastutik@ gmail.com

\section{INTRODUCTION}

Differences in the genotype variant of human papilloma virus (HPV) are found to occur in many regions in Indonesia. The most dominant HPV genotype found in Jakarta was HPV 52 followed by HPV 16, 39, 51, and 18, in Bali was HPV 52 followed by HPV 16, 18, 51 and 56, whereas in Tasikmalaya was HPV 18 followed by HPV 52, 16,39 and 56. ${ }^{1}$ A Research done in Jakarta in 2003 found that HPV 16 was the most dominant followed by HPV 18 and 52. ${ }^{2}$ Research in Bandung in 2014 on squamous cell carcinoma type of invasive cervical carcinoma found that the most dominant HPV was HPV 16 followed by HPV 18, 45 and $52 .{ }^{3}$ Other studies in Bandung in 2014 on ICC also found that the most dominant HPV was HPV 16 followed HPV 18, 45 and $52 .{ }^{4}$ However, until now, the HPV genotype found in patients with invasive cervical carcinoma in Surabaya is still unnown.

Two vaccines have been licensed. The first one is quadrivalent vaccines that protect against HPV16, 18, 6 and 11 , and the second one, bivalent vaccines protect against HPV16 and $18 .^{5}$ HPL 16 L1 VLP immunization is expected to protect against HPV 16 infection but does not provide protection against other HPV genotypes . The current VLP vaccine generation contains only two types of HPV which are 16 and 18. HPV 16 causes 50$60 \%$ of cases of ICC while HPV 18 causes $10-12 \%$ of ICC cases. $100 \%$ protection with a target of $70 \%$ required vaccine that induces significant cross-protection against other oncogenic HPV types. If such crossprotection can be claimed to occur, then the mechanism is unclear, because the experimental evidence suggests 
that the antibodies produced by VLP are specific. ${ }^{6}$ Polyvalent vaccines are expected to reach the market, a vaccine that includes four or five high-risk HPV genotypes that can prevent $80-90 \%$ incidence of cervical cancer. Regarding to the geographical differences in the prevalence of high-risk HPV-specific types, polyvalent vaccines need to be adjusted for the use in different countries.7 The prevalence of HPV genotypes causing ICC in every region of Indonesia, especially Surabaya, should be known. This research needs to be done to obtain data about the prevalence of HPV genotype infection caused by ICC in Indonesia especially in Surabaya so it can provide protection and prevention according to the HPV genotype.

In 2012 cervical cancer is the most common cancer among women in 45 countries in the world with a death rate of 266,000. Mortality varies in many regions of the world, less than 2 per 100,000 in West Asia. ${ }^{8}$ Cervical cancer disease reached the highest prevalence in Indonesia in 2013, which was 98. 692 cases $(0.8 \%)$ and 21,313 cases of it was found in East Java. ${ }^{9}$ From a research done in Dr. Soetomo Hospital in 2011, it was found that there was 1479 cases of cervical cancer from 2006 to $2010 .^{10}$ This data shows that the incidence of invasive cancer is very high and needs special attention, hence, the information about HPV genotype which can cause invasive cervical carcinoma (ICC) in Dr. Soetomo Hospital is important and can be used as a basic knowledge to give vaccination according to the HPV genotype in Surabaya.

Various studies have demonstrated the heterogeneity of HPV genotype variants. Data worldwide show that HPV 16 was found to be the most dominant followed by HPV 18, 31, 56. In East Africa, the most dominant genotype is HPV 52, followed by HPV 16, 18, 53. In Central America, the most prevalent genotype is HPV 16, followed by HPV 31, 18, 53. In South America, the most dominant genotype is HPV 16 , followed y 58, 18, 45. In North America, the most dominant genotype is HPV 16, followed by HPV 53, 18, 51. In Western Europe, the most dominant genotype is HPV 16 , followed by HPV 31,18 , 66. In Northern Europe, the most dominant genotype is HPV 16, followed by HPV 16, 18 , 31, 33. In South Europe, the most dominant genotype is HPV 16, followed by HPV 66, 45, 31. In Western Europe the most dominant genotype is HPV 16 , followed by HPV 18, 31, 35. In East Asia except Japan and Taiwan the most dominant genotype is HPV 16, followe by HPV 18, 58, 52. In Japan and Taiwan, the most dominant genotype is HPV 52, followed by HPV 16, 51, 35, 18. In Southeast Asia the most dominant genotype is HPV 16 followed by HPV 18, 58, 81. In South-Central Asia, the most dominant genotype is HPV 16 , followed by HPV 42, 56, JC9710 and HPV $18 .{ }^{11}$ HPV genotypes that cause ICC in Jakarta, Bali, Tasikmalaya and Bandung vary widely, therefore, this research needs to be done to know the HPV genotypes which cause ICC in Dr. Soetomo Hospital Surabaya.

\section{MATERIALS AND METHODS}

This research was an explorative research with cross sectional design. The aim of the study is to determine the HPV genotype's variants and the most common HPV genotype that found in invasive cervical carcinoma patients (squamous cell carcinoma, adenocarcinoma, adenosquamous carcinoma) who are treated in Dr. Soetomo Hospital Surabaya.

This study has received permission from the Research Ethics Committee of Dr. Dr. Soetomo Hospital Surabaya with letter number of 504/Panke.KKE/VIII/2016. Paraffin blocks of patients who have been diagnosed as invasive cervical carcinoma (squamous cell carcinoma, adenocarcinoma, adenosquamous carci-noma) in Dr. Soetomo Hospital Surabaya during the period of January 1 to December 31, 2013, were collected, and as many as 523 specimens were obtained. From those specimens, we took 30 specimens and divided them into SCC, AD and ASC (10 specimens each).

The selection process of paraffin block samples used purposive random sampling, and was assisted by Anatomical Pathologist. Anatomical Pathologists performed sorting and checking (microscopy re-examination) to make sure that the tissue samples in both slides and paraffin blocks originated from 1 subject of invasive cervical carcinoma patient. This selection process is performed on all sample studies from other subjects.

Samples of paraffin blocks were cut and then went through deparafinization process using NucleoSpin ${ }^{\circledR}$ Tissue kit (MACHEREY-NAGEL), DNA extraction using QIAamp® DNA FFPE Tissue kit and PCR process, AB ANALITICA). This test can detect $40 \mathrm{HPV}$ genotypes of HPV $6,11,16,18,26,31,33,39,40,42$, $43,44,45,51,52,53,54,55,56,58,59,61,62,64,66$, $67,68 \mathrm{a}, 68 \mathrm{~b}, 70,71,72,73,81,82,83,84,87,89,90$.

\section{RESULTS AND DISCUSSION}

\section{Age distribution of invasive cervical carcinoma patients}

The youngest age obtained from this study was 30 years old and the oldest was 74 years old, with invasive cervical carcinoma patients' mean age of 49.53 years. Observations were made by grouping 
ages into five groups and span of 10 years. The age group of which the invasive cervical carcinoma patients were most found was the 40-49 years old group $(53.3 \%)$ (Table 1$)$.

Table 1. Characteristics of patients with invasive cervical carcinoma

\begin{tabular}{ccc}
\hline Age & Frequency & $(\%)$ \\
\hline $30-39$ & 3 & 10.0 \\
$40-49$ & 16 & 53.3 \\
$50-59$ & 7 & 23.3 \\
$60-69$ & 3 & 10.0 \\
$70-70$ & 1 & 3.3 \\
\hline Total & 30 & 100.0 \\
\hline
\end{tabular}

The number of patients with squamous cell carcinoma subtype based on their age groups were 1 case in the 3039 years old group, 5 cases in 40-49 years old group, 1 case in 50-59 years old group, 2 cases in 60-69 years years old group, and 1 case in 70-79 years old group. The number of patients with adenocarcinoma subtype based on their age groups were 1 case in 30-39 years old group, 7 cases in 40-49 years old group, and 2 cases in 50-59 years old group. The number of patients with adenosquamous carcinoma subtype based on their age groups were 1 case in 30-39 years old group, 4 cases in 40-49 years old group, 4 cases in 50-59 years old group, and 1 case in 60-69 years old group (Figure 1).

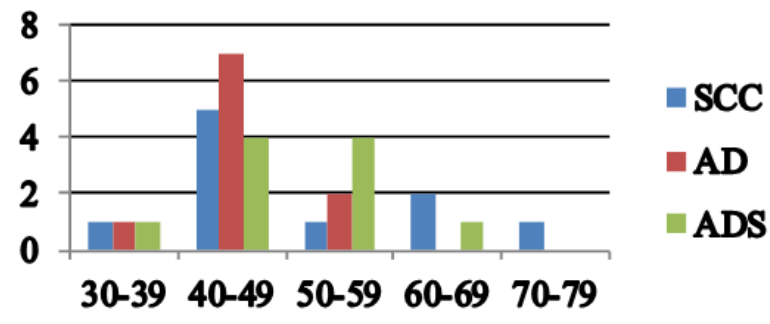

Figure 1 Distribution of invasive cervical carcinoma by age and SCC, AD and ADS subtype

\section{Distribution and prevalence of human papilloma virus genotype in squamous cell carcinoma}

Samples from paraffin blocks of 10 specimens from ICC patients' cervix with ICC subtypes of squamous cell carcinoma were genotyped and HPV infection 16 was found in a single infection of four specimens whereas multiple infections were found in another one specimen. HPV18 was found in a single infection of three specimens. HPV 45 was found in one sample, in both single and multiple infections. HPV 56 was found in a single infection of a specimen (Table 2).
Table 2. Distribution of human papilloma virus' genotype in squamous cell carcinoma

\begin{tabular}{lcccc}
\hline HPV & \multicolumn{2}{c}{ HPV Infection } & \multicolumn{2}{c}{ Total } \\
\cline { 2 - 5 } Type & Single & Multiple & N & $\%$ \\
\hline HPV16 & 4 & 1 & 5 & 50 \\
HPV18 & 3 & & 3 & 30 \\
HPV45 & 1 & 1 & 2 & 20 \\
HPV56 & 1 & & 1 & 10 \\
\hline
\end{tabular}

Samples from paraffin blocks of 10 adenocarcinoma subtype ICCS patients were genotyped and four negative specimens were found. HPV 6 is found in multiple infections of two specimens. HPV 16 was found in a single infection of a specimen. HPV18 was found in a single sample infection and multiple infections of one specimen. HPV 45 was found in multiple infections of two specimens. HPV $68 \mathrm{~b}$ and 72 were found in multiple infections of each specimen (Table 3).

Table 3. Distribution of human papilloma virus' genotype in adenocarcinoma

\begin{tabular}{ccccc}
\hline HPV & \multicolumn{2}{c}{ HPV Infection } & \multicolumn{2}{c}{ Total } \\
\cline { 2 - 5 } Type & Single & Multiple & N & $\%$ \\
\hline Negative & & & 4 & 40 \\
HPV 6 & & 2 & 2 & 20 \\
HPV16 & 1 & & 1 & 10 \\
HPV18 & 2 & 1 & 3 & 30 \\
HPV45 & & 2 & 2 & 20 \\
HPV68b & & 1 & 1 & 10 \\
HPV 72 & & 1 & 1 & 10 \\
\hline
\end{tabular}

Distribution and prevalence of human papilloma virus genotype in adenosquamous carcinoma

Table 4. Distribution of genotype human papilloma virus in adenosquamous carcinoma

\begin{tabular}{ccccc}
\hline HPV & \multicolumn{2}{c}{ HPV Infection } & \multicolumn{2}{c}{ Total } \\
\cline { 2 - 5 } Type & Single & Multiple & $\mathrm{N}$ & $\%$ \\
\hline Negative & & 1 & 1 & 10 \\
HPV 6 & & 1 & 1 & 10 \\
HPV16 & 1 & & 1 & 10 \\
HPV18 & 6 & & 6 & 60 \\
HPV45 & 1 & & 1 & 10 \\
HPV59 & & 1 & 1 & 10 \\
\hline
\end{tabular}
Distribution and prevalence of human papilloma
virus genotype in invasive cervical carcinoma

Samples from paraffin blocks of 30 ICC patients were genotyped and five negative specimens were found. HPV 16 was found in six specimens in the form of a single infection and one specimen multiple infection, 
HPV 18 was found in 12 specimens with single infection and one specimen in multiple infections. HPV 45 was found in one specimen in a single infection and three specimens with multiple infections. HPV 56 was found in a single infection specimen and HPV 68b, 59 and 72 were each found in one specimen with multiple infections (Table 5).

Table 5. Genotype distribution of human papilloma virus in invasive cervical carcinoma

\begin{tabular}{ccccc}
\hline HPV & \multicolumn{2}{c}{ HPV Infection } & \multicolumn{2}{c}{ Total } \\
\cline { 2 - 5 } Type & Single & Multiple & $\mathrm{N}$ & $\%$ \\
\hline Negative & & & 5 & 16.67 \\
HPV 6 & & 3 & 3 & 10 \\
HPV 16 & 6 & 1 & 7 & 23.32 \\
HPV 18 & 12 & 1 & 13 & 43.32 \\
HPV 45 & 2 & 3 & 5 & 16.67 \\
HPV 56 & 1 & & 1 & 3.32 \\
HPV & & 1 & 1 & 3.32 \\
68b & & 1 & 1 & 3.32 \\
HPV 59 & & 1 & 1 & 3.32 \\
HPV 72 & & & & \\
\hline
\end{tabular}

Persistent infection of the human papilloma virus (HPV) is known to be the etiology of invasive cancer. ${ }^{12}$ Based on the IARC classification, the HPV's strain / genotype is divided into 4 group. The first group consists of HPV $16,18,31,33,35,39,45,51,52,56,58$ and 59, which are carcinogenic to humans and are recognized as causes of cervical cancer. Group 2A, which consists of genotype HPV 68 may be carcinogenic to humans. Carcinogenic characteristics have been proven despite the limited epidemiological data. Group 2B, which consists of HPV 26, 53, 66, 67, 70, 73 and 82, may be carcinogenic, but the data are also limited. Group 3 which consists of HPV 6 and 11, is not classified as carcinogenic to humans. There is no evidence that those HPV genotypes are associated with cancer. ${ }^{8}$

It is estimated that approximately 291 million women worldwide with normal cervical cytology are HPV DNA carriers, of which approximately $32 \%$ are infected with HPV 16 and 18 or both. ${ }^{11}$ However HPV infection is an infection limited to cell responses that mediate immunity to initiate infection clearance and regression of lession induction. ${ }^{13}$ There appears to be a shift in the distribution of HPV from normal cytology to Cervical Intraepithelial Neoplasia (CIN) which later develops into invasive cancer. It has been found that infection by hrHPV type 16 is the major HPV infection in cervical cancer. ${ }^{14}$

\section{Age distribution of invasive cervical carcinoma patients}

From this study we found that most of invasive cervical carcinoma patients were between $40-49$ years old (16 cases), followed by 50-59 years old ( 7 cases) and the mean age was 49,53. The results of this study were consistent with the research done by Jan'car et al. (2009) which found that women in the age of 40-49 years old suffered most from ICC, followed by 50-59 years old women. The results of this study are also in accordance with research conducted by Tobing et al. (2014) in Bandung where the average age of ICC patients was 49.4 years old. Research conducted by Vet et al. (2008) in Bali, Jakarta and Tasikmalaya found that women between 35-44 years suffered the most from ICC. This study is in accordance with research conducted by Achmadi et al. (2011) in Dr. Soetomo Hospital Surabaya which showed that ICC patients were mostly in the age of 40-49 years old, followed by 50-59 years old. ${ }^{15,4,1,10}$

The 40-49 years age range which is observed in women with HPV is at least based on the potential causes. The first hypothesis is that impaired immune responses, as a result of hormonal changes in menopause period, somehow induce reactivation, and there may be a very low self-replicating HPV latent infection, with undetectable levels. If this is the primary mechanism of agerelated HPV patterns, however, it should be observed in postmenopausal women in all regions of the world at a certain age. The second interpretation is a change in the sexual behavior of women and their partners in middle age. ${ }^{11}$

\section{Genotype distribution of human papilloma virus in squamous cell carcinoma}

Samples from paraffin blocks of 10 specimens from cervical patients with squamous cell carcinoma subtypes ICC were genotyped and HPV infection 16 was found in a single infection of four specimens and multiple infections in one specimen. HPV18 was found in a single infection of three specimens, HPV 45 each found one sample in both single and multiple infections, while HPV 56 was found in a single infection of a specimen.

Worldwide, including the Asia, Europe, North America and Australia hrHPV 16 genotype is the most dominant type in causing SCC followed by hrHPV 18, 31, 33. ${ }^{17}$ Research conducted by Bao et al. (2008) in Asia found that the 16th hrHPV genotype was the commonest cause of SCC followed by hrHPV 18, 58, 52 and 35. This study also corresponds to a study conducted by $\mathrm{Xu}$ et al. (2015), Li et al. (2015) and Jancar et al. (2009) in southern China, Shaanxi and Slovenia which all found that the most dominant genotype in causing SCC was hrHPV 16 followed by genotype hrHPV $18.18,19,20,{ }^{15}$

This study is also in accordance with the research conducted by Schellekens et al. (2003) in Jakarta, Sahir- 
atmadja et al. (2014) in Bandung, which found that hrHPV 16 was the most dominant genotype followed by genotype hrHPV 18, 52 and 45. The Croatian study conducted by Had isejdic et al. (2006) also showed the same results in obtaining that hrHPV 16 was the most dominant genotype, followed by hrHPV 18 genotype. The same is also found in research conducted by Tornesello et al. (2011) which found that the most dominant genotype was hrHPV 16 genotype followed by hrHPV 18 genotype. Research conducted by Odida et al. (2008) also found that the most dominant genotype was hrHPV 16 genotype followed by hrHPV 18 genotype. hrHPV 16 genotype was found in all studies on squamous cell carcinoma type ICC as the most dominant genotype followed by hrHPV 18 and other hrHPV genotype., ${ }^{2,3}$, $21,22,23$

As many as 10 SCC specimens showed that their squamous epithelium supported viral replication, in other words, they were found to be positive. Consequently, the number of HPV DNA episome copies which are replicated and integrated with infected host cells are very high and therefore can be very easily detected. This may also be the reason why the prevalence of HPV in SCC is higher than in other ICC subtypes. ${ }^{24}$ In addition, HPV 16 had a higher viral load in SCC than in AD and ASC. ${ }^{25} \mathrm{HPV} 16$ in this study was the most dominant cause of SCC in Dr. Soetomo Hospital, followed by HPV 18 and 45. HPV 16, 18 and 45 are more likely to be integrated into the human genome in episome form so that it can easily induce cancer cell's growth. ${ }^{26}$ The oncogenic potency of HPV 16 and 18 may be due to the different ability to avoid host' immune system compared to other oncogenic HPV. ${ }^{27}$

\section{Genotype distribution of human papilloma virus in adenocarcinoma}

Paraffin blocks' samples of 10 specimens from adenocarcinoma subtype ICC cervix were genotyped and four negative specimens were found. HPV 6 wass found in multiple infections of two specimens. HPV 16 was found in a single infection of a specimen. HPV18 was found in a single, two-sample infection and a single infection of a specimen. HPV 45 was found in multiple infections of two specimens, whereas, HPV $68 \mathrm{~b}$ and 72 were found in multiple infections of each specimen.

In studies around the world, including in Asia, Europe, North America and Australia, the most dominant genotype was hrHPV 18 genotype, followed by hrHPV 16 and $45 .{ }^{17}$ Research conducted by Bao et al. (2008) in Asia found the most dominant genotype was hrHPV 18, followed by hrHPV 16, 45 and 58 genotypes. This study was also in accordance with a study conducted by Xu et al. (2015) which found that the most dominant genotype was hrHPV 18, followed by hrHPV 16 genotype. Research conducted in Jakarta by Schellekens et al. (2003) also showed the same result, the most dominant genotype was hrHPV 18 followed by the hrHPV 16 genotype. The study conducted by Pirog et al. (2014) found that the world's most dominant genotype was hrHPV 16, followed by hrHPV 18 and 45 genotypes, while other hrHPV genotypes were found with lower frequencies. Research conducted by Had isejdic et al. (2006) showed similar result with this study, where the most dominant genotype observed was hrHPV 18, followed by hrHPV 16 genotype. This study was in accordance with the study by Odida et al. (2008) which found that the most dominant genotype was hrHPV 18 followed by hrHPV 16 genotype. . $^{18,19,2,24,21}$

Differences in the prevalence of HPV types in the world and small-scale studies in different areas (including this study) may be due to the number of samples being involved. The sample in this study found four negative specimens from 10 specimens. Previous studies have identified that the use of FFPE for detecting HPV in adenocarcinoma can result in lower HPV detection rates compared with fresh tissue. Glandular epithelium also does not support the production of HPV infection so that no HPV DNA episomal accumulation is replicated in the infected cells, and only a limited number of low copies of HPV DNA are integrated into the cell genome making it difficult to detect. ${ }^{24}$

This study showed that HPV 18 was the most dominant genotype, followed by HPV 16. This event was because in gland cells, HPV 18 showed a high integration level with host' genome compared to HPV $16 .{ }^{28}$ Culen et al. (1991) detected a significant difference in viral integration between HPV 16 and 18, suggesting that many cases of HPV 16 positive cervical cancers contain only the episome form of the virus. Moreover, HPV 18 also showed earlier integration compared to HPV $16 .^{29}$

\section{Genotype distribution of human papilloma virus in adenosquamous carcinoma}

Samples of paraffin blocks of 10 specimens from ICC cervical patients of subtype adenosuamous carcinoma were genotyped and a negative specimen was found. HPV 6 is found in multiple infections in one specimen. HPV 16 was found in a single infection in one specimen. HPV18 was found in a single infection in six specimens. HPV 45 was found in a single infection in one specimen and HPV 59 was found in multiple infections in one specimen.

hrHPV 18 genotype is the most dominant genotype in adenosquamous carcinoma in the worldwide, Asia, 
Europe, North America, South America and Australia, followed by hrHPV 16, 31, 33, 52 and 58 genotypes. ${ }^{30}$ This study also corresponds to a study by $\mathrm{Xu}$ et al. (2015) in China which showed that the most dominant genotype was hrHPV 18 followed by hrHPV 16 and 45 genotypes. This study was also in accordance with a study by Schellekens et al. (2003) which found that the most dominant genotype was hrHPV 18 followed by hrHPV 16 and 45 genotypes. This study was also in accordance with a study conducted by Holl et al. (2015) in Europe which obtained that the most dominant genotype was hrHPV 18 followed by hrHPV 16 and 45 genotypes. Research conducted by Jan'car et al. (2009) also found the same result where the genotype hrHPV 18 is the most dominant genotype, followed by hrHPV 16 and 45 genotypes. ${ }^{19,2,30,15}$

From 10 ASC specimens in this study, there was only one negative specimen found. This was because the glandular epithelium did not support the production of HPV infection so that no HPV DNA epicomes were replicated in the infected cells, and only a limited number of low copies of HPV DNA were integrated into the cell genome. ${ }^{24} \mathrm{HPV} 18$ was the most dominant genotype followed by HPV 16, and 45. Yoshida et al. (2009) found integration rate of positive HPV 18 in $63.6 \%$ of cases, for both squamous and glandular components, compared with only $14.3 \%$ and $16.7 \%$ in positive HPV 16 and HPV18 appearing dominant with pure integration. Cullen et al. (1991) detected a significant difference in viral integration between HPV 16 and 18 , and showed that many HPV 16 positive cervical cancer cases only contained virus episome formation. $^{28,29}$

\section{Distribution and prevalence of human papilloma virus genotype in $\mathbf{3 0}$ patients with invasive cervical carcinoma}

Samples of paraffin blocks of 30 specimens from ICC cervical patients were genotyped and five negative specimens were found. HPV 16 was found in six specimens in the form of a single infection and one specimen in the form of multiple infection, HPV 18 was found in 12 specimens with single infection and one specimen in multiple infections. HPV 45 was found in specimens in single infection and three specimens with multiple infections. HPV 56 was found in a single infection specimen and HPV 68b, 59 and 72 were each found in one specimen with multiple infections.

This study differs from the prevalence of ICC in the worldwide, South America, North America, Europe, Asia and Africa which found that hrHPV 16 was the most dominant genotype followed by the hrHPV 18, 33, 31,45 genotypes. $^{30,17}$ Similarly in Jakarta, according to research conducted by Scellekens et al. (2003) the prevalence of hrHPV 16 genotype was the hhighest compared to hrHPV 18, 52 and 45 genotype. Research conducted by Vet et al. (2008) in Jakarta showed that HPV 52 was the most dominant genotype followed by HPV 16, 39, 51, and 18, in Bali the most dominant genotype was HPV 52 followed by HPV 16, 18, 51 and 56 while in Tasikmalaya the most dominant genotype was HPV 18 followed by HPV 52, 16,39 and 56..$^{2,1}$

Smith et al. (2007) states that hrHPV 16 genotype is the most dominant genotype all over the world, followed by hrHPV 18, 45 and 31 genotypes. ${ }^{30}$ This research also corresponds to the research done towards the ICC etiology (hrHPV genotypes) in Canada which found the most dominant genotype wass hrHPV 16 followed by hrHPV 18, 52 and 45. ${ }^{14}$ Bao et al. (2008) showed that the most dominant hrHPV genotype of ICC in Asia was hrHPV 16 genotype followed by the hrHPV 18, 58, and 33 genotypes. Research conducted by de Sanjose et al. (2007) also showed that hrHPV 16 genotype predominated the cause of ICC followed by HPV 18, 45. A study about HPV genotypes that causes ICC in Indonesia conducted by Sahiratmaja et al. (2014), which was done in Bandung by Tobing et al. (2014), found that the most dominant genotype was HPV 16 followed by HPVs 18, 45 and 52. This may be because the study specimens taken were ICC type SCC alone whereas in this study. the specimens were taken from a combination ICC, AD and ASD sample. ${ }^{18,11,3,4}$

The heterogeneity of HPV variants in studies held in various regions of Indonesia including this study depicted differences in data which exist worldwide except in East Africa, Japan and Taiwan, and was possibly due to the excessive sample size and geographical tendency to use HPV testing with a certain sensitivity to detect certain types of HPV. ${ }^{32}$ In this study HPV18 was the most dominant followed by HPV 16 and 45.20 of 30 specimens were subtypes AD and ASC of SCC which were closely related to HPV 18 and 10. SCC specimens related to HPV 16. HPV 16 found in shape of episome and was integrated with host genome well on SCC than on AD and ASC which were only non integrated episomes. HPV 18 is found integrated even in premalignant and in AD and ASC. The specificity of HPV 18 specificity against AD and ASC is unknown. $25,24,28,29,33$

HPV genotype variants found in Dr. Soetomo Hospital Surabaya are dangerous genotypes and are the main cause of ICC in the world, so it needs proper precautions and preventive steps so it can suppress the incidence of ICC in Surabaya. 


\section{CONCLUSION}

There was a single infection of HPV genotype 16, 18, 45, 56 and multiple genotype infection of hr $+\mathrm{hrHPV}$ $16+45$ in squamous cell carcinoma, there was a single infection of hrHPV genotype 16,18, multiple genotype infection $\mathrm{hr}+\mathrm{hrHPV} 68 \mathrm{~b}+72$ and genotype $\mathrm{lr}+$ hrHPV $6+18+45$ in adenocarcinoma, there was a single infection of hrHPV genotype 16, 18, 45 and multiple genotype infection $l r+$ hrHPV $6+59$ in adenosquamous carcinoma. There was no multiple infection of $\mathrm{hr}+\mathrm{hrHPV}$ genotype in Dr. Soetomo Hospital. The HPV18 genotype had the highest prevalence followed by HPV 16, 45, 56, 59 in invasive cervical carcinoma in Dr. Soetomo Hospital.

\section{REFERENCES}

1. Vet JNI, de Boer BEWM, Siregar B, Lisnawati, BS, et al. Prevalence of human papillomavirus in Indonesia: a population-based study in three re-gions. British Journal of Cancer. 2008;99:214-8.

2. Schellekens MC, Dijkman A, Aziz MF, et al. Prevalence of single and multiple HPV types in cervical carcinomas in Jakarta, Indonesia. Gynecologic Oncology. 2004;93:49-53.

3. Sahiratmadja E, Tobing MDL, Dewayani BM, et al. Multiple human papilloma virus infections predominant in squamous cell cervical carcinoma in Bandung. Universa Medicina, 2014;33:58-64.

4. Tobing MDL, Edhyana S, Dinda M et al. Human papillomavirus genotypes profile in cervical cancer patients at dr. Hasan Sadikin general hospital, Bandung, Indonesia. Asian Pacific Journal of Cancer Prevention. 2014;15(14):5781-85.

5. Stanley M, Pinto LA, Trimble C. Human papillomavirus vaccines - immune responses. Vaccine. 2012;30(SUPPL.5):F83-F87.

6. Stanley M. Immune responses to human papillomavirus. Vaccine. 2006;1:16-22.

7. Hausen H. Papillomaviruses and cancer: from basic studies to clinical application. Nature Reviews Cancer. 2002;2:342-50.

8. IARC Press. WHO classification of tumours of the female reproductive organs. 2014. p. 207-52.

9. Kementerian Kesehatan RI, Pusat Data dan Informasi Kesehatan. Data dan Informasi Kesehatan Situasi Penyakit Kanker. Igarss; 2015. 1, p. 1-5.

10. Achmadi, Brahmana AT, Suhatno. Karakteristik Penderita Kanker Serviks 2006-2010 di RSUD dr. Soetomo. Majalah Obstetri \& Ginekologi. 2011;18 (3): 28-33.

11. de Sanjosé S, Diaz M, Castellsague $X$, et al. Worldwide prevalence and genotype distribution of cervical HPV in women with normal cytology. Lancet Infect Dis. 2007;7(7):453-9.

12. Bosch FX and de Sanjose S. Cervical human papillomavirus prevalence in 5 continents: meta-analysis of 1 million women with normal cytological findings. The Journal of infectious diseases. 2010;202 (12):1789-99.

13. Stanley M/ HPV-immune response to infection and vaccination. Infectious Agents and Cancer. 2010;5: 19.

14. Coutlee F, Ratnam S, Ramanakumar AV et al. A clinically relevant, syngeneic model of spontaneous, highly metastatic B16 mouse melanoma. Anticancer Research. 2010;30(12): 4799-804.

15. Jancar N, Kocjan BJ, Poljak M et al. Distribution of human papillomavirus genotypes in women with cervical cancer in. European Journal of Obstetrics \& Gynecology and Reproductive Biology. 2016; 145:184-8.

16. Tobing MDL, Edhyana S, Dinda M, et al. Human papillomavirus genotypes profile in cervical cancer patients at dr. Hasan Sadikin general hospital, Bandung, Indonesia. Asian Pacific journal of cancer prevention. 2014;15(14):5781-5.

17. Clifford GM, Smith JS, Plummer M, Munoz NFS. Human papillomavirus types in invasive cervical cancer worldwide: a meta-analysis. British Journal of Cancer. 2003;88(1):63-73.

18. Bao YP, Li N, Smith J, Qiao YL. Human papillomavirus type distribution in women from Asia: A meta-analysis. International Journal of Gynecological Cancer. 2008;18(1):71-9.

19. $\mathrm{Xu} \mathrm{XX,} \mathrm{Zhou} \mathrm{JS,} \mathrm{Yuan} \mathrm{SH,} \mathrm{Yu} \mathrm{H.} \mathrm{Distribution} \mathrm{of}$ HPV Genotype in Invasive Cervical Carcinoma and Cervical Intraepithelial Neoplasia in Zhejiang Province, Southeast China: Establishing the Baseline for Surveillance. Int. J. Environ. Res. Public Health. 2015:10794-805.

20. Li Y, Peng L, Seto E., 2015. Histone Deacetylase 10 Regulates the Cell Cycle G2/M Phase Transition via a Novel Let-7-HMGA2-Cyclin A2 Pathway. Molecular and cellular biology, 35(20), pp.354765.

21. Hadzisejdic I, Simat M, Bosak A. Prevalence of human papillomavirus genotypes in cervical cancer and precursor lesions. Coll. Antropol. 2006; 30(11): 879-83.

22. Tornesello ML, Losito S, Benincasa G, et al. Human papillomavirus (HPV) genotypes and HPV16 variants and risk of adenocarcinoma and squamous cell carcinoma of the cervix. Gynecologic Oncology. 2001;121(1):32-42.

23. Odida M, de Sanjose S, Quint W et al. Human Papillomavirus type distribution in invasive cervical cancer in Uganda. BMC Infectious Diseases. 2008;7:1-7. 
24. Pirog EC, Lloverans B, Molijn A et al. HPV prevalence and genotypes in different histological subtypes of cervical adenocarcinoma , a worldwide analysis of 760 cases. Modern Pathology. 2014; (27):1559-67.

25. Pirog EC, Kleter B, Olgac S, et al. Prevalence of human papillomavirus DNA in different histological subtypes of cervical adenocarcinoma. The American Journal of Pathology. 2000;157(4):1055-62.

26. Sykes P, Gopala K, Tan AL, et al. Type distribution of human papillomavirus among adult women diagnosed with invasive cervical cancer (stage $1 \mathrm{~b}$ or higher) in New Zealand. BMC Infectious Diseases, 2014:14(374);1-9.

27. Burk RD, Terai M, Gravitt PE, et al. Distribution of human papillomavirus types 16 and 18 variants in squamous cell carcinomas and adenocarcinomas of the cervix. Cancer Research. 2003:11(12):7215-20.

28. Yoshida T, Sano T, Oyama T, et al. Prevalence, viral load, and physical status of HPV 16 and 18 in cervical adenosquamous carcinoma. Virchows Archiv. 2009;455(3):253-9.
29. Cullen AP, Reid R, Campion M, Lorinz AT. Analysis of the physical state of different human papillomavirus DNAs in intraepithelial and invasive cervical neoplasm. Journal of Virology. 1991:65(2); 606-12.

30. McCluggage WG, Pirog EC, De Souza SC et al. Cervical glandular neoplasias: Results from a $\mathrm{Eu}-$ ropean multinational epidemiological study infectious causes of cancer. International Journal of Cancer. 1991;20(5):2858-68.

31. Smith JS, Lindsay L, Hoots B, et al. Human papillomavirus type distribution in invasive cervical cancer and high-grade cervical lesions: A metaanalysis update. International Journal of Cancer. 2007;121(3):621-32.

32. Chan PKS, Cheung TH, Tam AOY, et al. Biases in human papillomavirus genotype prevalence assessment associated with commonly used consensus primers. International Journal of Cancer. 2006;118 (1):243-45.

33. Bosch FX, Lorincz A, Munoz N et al. The causal relation between human papillomavirus and cervical cancer. J Clin Pathol 2002;55(4):244-65. 